\title{
STRUCTUREEL ONDERZOEK VAN HET SRANAN
}

\author{
DOOR
}

\section{J. VOORHOEVE}

\section{De Linguistische Analyse}

Naar aanleiding van mijn proefschrift ${ }^{1}$ ) werden van Surinaamse zijde principiële bezwaren geopperd tegen de toepassing van de moderne structurele methode van analyse op talen als het Sranan. Men ging zelfs zover te beweren: „Onbedoeld wordt de slechts gedeeltelijke bruikbaarheid van de moderne structurele grammatica voor de beschrijving van Creolentalen gedemonstreerd" ${ }^{2}$ ). Het zou van weinig begrip voor de overtuiging der critici getuigen, wanneer ik op de ingeslagen weg voortging, zonder de bruikbaarheid van deze methode aan te tonen.

Het is moeilijk na te gaan, op grond waarvan de critici deze opmerking plaatsten. Ik heb in mijn proefschrift de resultaten van een analysemethode nooit zonder meer tegen de methode laten getuigen. De foutieve resultaten van HALL werden steeds herleid tot een verkeerde toepassing van de structurele methode of tot fouten in het geanalyseerde materiaal. Men heeft dus niet op grond van mijn critische notities de structurele methode kunnen verwerpen. Maar het zou kunnen zijn, dat fouten in de resultaten van mijn eigen voorlopige analyse tot dit oordeel voerde. Het lijkt mij echter verkeerd zonder meer een methode te beoordelen naar de resultaten, en zeker waar de auteur deze presenteert als voorlopige resultaten.

Het zou echter ook kunnen zijn, dat men de methode heeft verworpen om redenen, die geheel buiten het proefschrift om gaan. Ik kreeg dit vermoeden na lezing van een uitvoeriger beoordeling van mijn werk door LiCHTVELD $^{3}$ ). Hij ziet namelijk het Sranan als een taal met onduidelijk begrensde, in elkaar overlopende taalcategorieën. Ik weet niet waarop deze verrassende bewering (overigens vragenderwijze geuit) berust, maar wanneer hij gelijk heeft, zou inderdaad de structurele methode voor het

1) Voorstudies tot een beschrijving van het Sranan Tongo (Negerengels van Suriname). Amsterdam, 1953.

2) Vox Guyanae I, 1954, p. 48. - Het betreft hier een korte, niet-ondertekende bibliografische notitie. Ik mag deze dus beschouwen als een samenvatting van het oordeel van de redactie van Vox Guyanae.

3) W. I. Gids 35, 1954, p. 174-177. 
Sranan absoluut onbruikbaar zijn. De structurele taalkunde gaat uit van de praemisse, dat een taalcategorie bestaat, dank zij haar anderszijn dan andere taalcategorieën, dank zij haar duidelijke grenzen. In elkaar overlopende taalcategorieën bestaan niet voor de structurele taalkunde en worden via de structurele methode zeker niet gevonden. En eerlijk gezegd schiet ook mijn voorstellingsvermogen tekort bij deze in elkaar overlopende categorieën. Ik kan mij zeker een categorie voorstellen, die de Europese categorieën verbum en nomen omsluit, maar dan gaat het nog steeds om één categorie, die duidelijk te onderscheiden valt van andere categorieën, als bv. het pronomen.

De mening van LICHTVELD nadert naar mijn gevoel gevaarlijk dicht tot de in Suriname vaak gehoorde uitspraak: Het Sranan (Negerengels) heeft geen grammatica ${ }^{1}$ ). Natuurlijk zal men niet gauw iemand vinden, die bereid is deze uitspraak in al zijn naaktheid te verdedigen. Een taal zonder grammatica wordt immers niet verstaan, kan dus zijn sociale functie niet vervullen en is dus geen taal. Men komt tot deze uitspraak door een verkeerd begrip omtrent het verschijnsel grammatica. De grammatica wordt maar al te dikwijls (en niet alleen door leken) gezien als een systeem van geïsoleerde woorden (een woordenboek), ingedeeld in verschillende groepen (categorieën) als verbum en nomen. Het begrip grammatica is geleerd op sterk morphologische talen zoals het Latijn, waarin aan de woordvorm (de uitgang) duidelijk te zien is tot welke categorie het woord behoort. Hierdoor heeft men zich aangewend steeds geïsoleerde woorden te beschouwen. Wanneer in enige andersgebouwde taal aan de woordvorm zelf niet te zien is, tot welke categorie het woord behoort; wanneer met andere woorden eenzelfde woordvorm als verbum én nomen gebruikt kan worden, acht men de categorieën onduidelijk begrensd.

Wanneer Lich TVELD schrijft: ,,zijn in het Sr. Tg. niet alle ,,benamingen” enigszins gerundiaal .... zodat zij evengoed tot werkwoorden als tot naamwoorden .... kunnen dienen ?" ${ }^{2}$ ), dan is dit in wezen de hierboven gesignaleerde twijfel (nu in wetenschappelijke termen vertaald) omtrent de grammatica van het Sranan als duidelijke ordening der taalfeiten. $\mathrm{Bij}$ hem, op het voetspoor van enige romantische Africanisten, werd deze twijfel omgezet in geloof aan een prelogische grammatica als neerslag van een primitieve denkstructuur. Veel daarvan moest zelfs in Afrika hypothese blijven. Overdracht op het Sranan maakt dit echter tot een aantoonbare misvatting.

Voor ik echter het contrabewijs lever, wil ik eerst een poging doen het meningsverschil over de analysemethoden te overbruggen. LicHTVELD zegt met nadruk in zijn beoordeling, dat taalcategorieën betekeniseenheden zijn, groepen woorden met gelijke betekenisinhoud. Dit kan waar zijn en ik ben geneigd - hoewel ik mij over talphilosophische kwesties als deze niet positief durf uit te laten - hem hierin geheel gelijk te geven. Mits LichtVELD niet verlangt, dat hierop de analysemethode gebaseerd wordt. Het zou gemakkelijk zijn een caricatuur van een dergelijke methode te schetsen, een methode namelijk die zoekt naar betekeniseenheden: categorieën in het Sranan die zachtheid, bolheid, gladheid uitdrukken.

1) Zie hierover W. Gs Hellinga: De waarde der zg. mengtalen in de West. Taal en Tongval 3, 1951, p. 133-137.

2) W. I. Gids 35, 1954, p. 176. 
Hoezeer hij dus gelijk heeft, methodisch is dit een verkeerd uitgangspunt. De moderne linguistiek baseert zich dan ook terecht op de formele kenmerken. Alleen - en hiermee kom ik op de vorige opmerkingen terug men zoekt deze formele kenmerken niet uitsluitend aan de woordvorm (de morphologie, de uitgangen), maar evenzeer - of in talen als het Sranan zelfs bijna uitsluitend - in de combineerbaarheid met andere woorden en de plaats in de zin. Wanneer op deze wijze een categorie woorden gevonden is met gelijke formele kenmerken, wil ik gaarne achteraf met LicHTVELD naar de gemeenschappelijke betekeniseenheid zoeken.

Baseert men zich wel op de betekenis en onderzoekt men wel geïsoleerde woorden, dan ontdekt men een gemeenschappelijke betekenisinhoud in het verbum ,,heten” en het nomen ,,naam”. Wanneer dan bovendien nog beide betekenissen gedekt worden door dezelfde woordvorm nen (zoals in het Sranan), is de overtuiging gevestigd, dat men te maken heeft met eenzelfde woord, dat verbaal en nominaal kan optreden.

Op dit moment verlangt de lezer hopelijk het contrabewijs. Hopelijk, want dat zou betekenen, dat ik aan het oordeel van LichTVELD alle recht heb laten wedervaren, zoals mijn bedoeling was. Om dit bewijs te leveren moet ik eerst de volgens mij principiële methodische fout herstellen en het geïsoleerde woord nen terugplaatsen in een context. Vanuit deze context kan ik dan pas bewijzen, dat het woord nen (in deze context) tot een bepaalde scherp afgebakende taalcategorie behoort.

mi nen Juwan

ik heet Juwan

Ik heb dit voorbeeld met opzet zo ongunstig mogelijk gekozen voor mijn betoog. Men kan met enige goede wil (vóór de analyse) staande houden, dat men deze zin ook kan vertalen met: , ,mijn naam (is) Juwan”. Men kan echter via een analyse bewijzen, dat nen op deze plaats een verbum moet zijn.

De linguistiek maakt hiertoe gebruik van de zgn. substitutieproef. Men vervangt een woord of open plaats in de context door een ander woord, waarvan men de gebruiksmogelijkheden beter kent. Als men het woord nen in deze zin zou kunnen vervangen door een ontwijfelbaar verbum, dan moet ook nen (uitsluitend echter in deze context) een verbum zijn. Aangezien het bestaan van verba in het Sranan door LichtvelD betwijfeld wordt, kies ik hier een variant van de substitutieproef en voeg de ontkenning no aan de zin toe. Ik mak dus bovenstaande zin ontkennend. Van het woordje no is ons nu bekend, dat het tussen subject en praedicaat wordt geplaatst. Is het woord nen een verbum, dan zal no vóór nen moeten worden geplaatst, zoals hier ook inderdaad gebeurt:

mi no nen Juwan

ik niet heet Juwan

Wanneer het een substantivum was geweest, dan had nen tot het subject behoord en werd no achter nen geplaatst:

* mi nen no Jwwan

mijn naam niet Juwan

$\mathrm{Al}$ accepteert men hierna nog niet de termen verbum en substantivum, men kan niet ontkennen, dat er zeer duidelijke verschillen bestaan tussen nen (= heten) en nen (= naam). Op dezelfde wijze zijn nog vele andere verschillen tussen beide woorden nen te vinden. Ik hoop echter, dat de waarde van de moderne structurele methode (ook voor talen als het Sranan) aldus voldoende aangetoond is. 
Op de boven beschreven wijze wordt van situatie tot situatie de gebruikscategorie der Sranan-woorden bepaald. Hierna moet men echter verder gaan en het gemeenschappelijke element in alle identieke situaties ontdekken. Dat wil niet zeggen, dat men nu kan terugkeren naar het woordenboek. Wij komen nu tot een lijst van combinatiemogelijkheden van de taalcategorie. Zo ontdekt men, dat de verba in Sranan niet alleen no voorgeplaatst krijgen, maar ook combineerbaar zijn met ben, sa en $e$. Door differentiatie tussen de verschillende combinatiemogelijkheden ontdekt men bepaalde sub-categorieën als de hulpverba.

Het geïsoleerde woord in het Sranan behoort niet tot een bepaalde woordsoort (categorie), behalve enkele taaltechnische elementen als ben, $s a$ en $e$. De woordsoort kan men slechts vinden door de combinatiemogelijkheden van het woord in de taalsituatie te onderzoeken. Wil men hierna terugkeren tot het woordenboek, dan moet men dit voor een taal als het Sranan speciaal voor dit doel bruikbaar maken. Achter de woordvorm nen komt dan te staan:

1 heten (verbum), indien combineerbaar met ben, sa en $e$.

2 naam (substantivum), indien combineerbaar met de lidwoorden $a$ en wan.

Hierbij doet men dan een keuze uit de meest karakteristieke combinatiemogelijkheden.

\section{TAALONTWIKKELING OP HETERDAAD}

1. - Bij ons onderzoek naar voorzetselbepalingen in het Sranan ${ }^{1)}$ zijn wij gestuit op onzekerheden in de taalstructuur: duidelijke structuurregels (wetmatigheden dus) schenen onverklaarbare uitzonderingen toe te laten. Dit op zichzelf al zal de linguist verdacht voorkomen. Structuurregels zijn geen van boven af opgelegde normen, maar uit het taalgebruik afgeleide wetmatigheden. De taalstructuur is niet een door de onderzoeker aan de taal opgedrongen schema, maar een in de taalgebruikers onbewust levend systeem, met behulp waarvan zij hun taaluitingen vormen en de taaluitingen van anderen herkennen. Wanneer dus de linguist wetmatigheden meent te ontdekken en uitzonderingen daarop (die niet als versprekingen verklaard kunnen worden), is zijn eerste reactie dat dus de door hem gevonden wetten onvolledig of ongeldig zijn. Hij heeft een vreemd systeem op de taal gedrukt; in de uitzonderingen doorbreekt de taal dit vreemde systeem, dat voor deze taal dus geen waarde heeft. Uitzonderingen zijn voor de linguist noodseinen, die aangeven dat hij een verkeerd spoor volgt.

In ons geval echter bleek de wetmatigheid evident en ieder

1) Uitgevoerd in het kader van een uitgebreid onderzoek naar de taalstructuur van het Sranan in opdracht van WOSUNA, onder supervisie van Prof. Dr W. Gs Hellinga en Prof. Dr A. Reichling van de Universiteit van Amsterdam. 
ander systeem onbevredigend. Wij hebben hieruit moeten afleiden, dat deze uitzonderingen onzekerheden in de taalstructuur aantonen en de voorbode kunnen zijn van een toekomstige taalontwikkeling. Onze ervaringen liggen op zulk een beperkt terrein, dat wij af moeten zien van algemene conclusies en slechts het verschijnsel kunnen beschrijven zoals dit zich aan ons voordeed.

Wij moeten daartoe eerst de huidige situatie van het Sranan trachten te tekenen. Deze taal wordt in Suriname gesproken (1)door personen voor wie het de moedertaal is, en (2) door personen voor wie een Europese of Aziatische taal moedertaal is.

Velen horen wekelijks in de kerken Sranan spreken door Europeanen. Onder invloed van Europese zendelingen is een kanseltaal in Suriname ontstaan, die groot prestige heeft, als onder meer de taal van Bijbel en geestelijk lied. Men kan zelfs zeggen dat hiermee een vreemde taalnorm is ontstaan voor officieel gebruik van het Sranan. Iedere Surinamer weet hoe hij netjes moet spreken, al zal hij dit alleen bij min of meer officiële gelegenheden doen. Deze ,nette" taal wijkt tot zelfs in het gebruikte foneemsysteem af van het levende Sranan.

Voorts zijn de meeste taalgebruikers min of meer tweetalig. $\mathrm{Zij}$ beheersen naast hun moedertaal in meer of mindere mate ook het Nederlands, de officiële taal in Suriname en het enige toegestane onderwijsmedium.

Tenslotte heeft het Nederlandse taalsysteem of wat men daar voor houdt groot prestige in Suriname. Wij maakten kennis met een amateur-filoloog, die alle afwijkingen van het Nederlandse taalsysteem als strijdig met de logica trachtte te brandmerken.

De taalgebruikers komen via het Nederlands in aanraking met gezegden, die grote klank- en betekenisverwantschap vertonen met het Sranan, maar op andere wijze zijn geconstrueerd. Letterlijke vertaling kan dus taalvreemde constructies doen ontstaan. Het is duidelijk dat door imitatie van het taalgebruik van Sranan sprekende Europeanen en door letterlijke vertaling van klankverwante Nederlandse gezegden vreemde insluipsels in het taalgebruik kùnnen binnendringen. Het is echter evenzeer duidelijk, dat dit alleen daar zal gebeuren, waar de structuurregels niet met dwingende kracht in de taalgebruikers leven. Met andere woorden: de zwakke punten in de structuur van het Sranan worden het eerst aangetast. Wanneer de vreemde invloeden zich blijven voordoen kan men dus vooral op deze punten een nieuwe ontwikkeling verwachten. Hierom hebben wij deze studie kunnen noemen: taalontwikkeling op heterdaad. 
De voorbeelden werden ons verschaft door taalgebruikers voor wie Sranan de moedertaal is, maar die naast het Sranan een grote vaardigheid hebben verkregen in het Nederlands. Beide informanten werkten enige tijd in Nederland ${ }^{\mathbf{1}}$ ).

2. - Alvorens de uitzonderingen te bespreken, dienen wij een beknopt overzicht te geven van de wetmatigheden. Wij namen met de wire-recorder monologen op van twee tweetalige proefpersonen (Creolen uit de arbeidersklasse van Paramaribo). Hieruit werden alle voorzetselbepalingen geficheerd. De meeste fiches bleken plaatsbepalingen te bevatten. Plaatsbepalingen waren duidelijk te onderscheiden van andere bepalingen (op enige uitzonderingen na). De plaatsbepalingen werden opgebouwd volgens een bepaald systeem, dat verder in deze paragraaf geschetst zal worden.

2a. In de plaatsbepalingen zelf kan de richting van de handeling die daarop betrekking heeft niet worden uitgedrukt. Tegenstellingen tussen

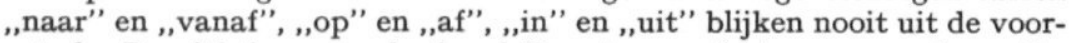
zetsels. De richting van de handeling ten opzichte van een bepaalde plaats kan alleen in de handeling zelf worden gegeven. Zo moeten dan ook voor ,komen naar” en ,komen van” twee verschillende verba worden gebruikt:

a e-kon

dape

a e-komopo dape

hij komt $+\leftarrow$ daar (= hij komt daarvandaan)

Het spreekt vanzelf dat wij dus een onderscheid dienen te maken tussen (1) verba die een richting-naartoe betekenen: go (gaan), gowe (weggaan), kon (komen), poti (plaatsen) en waarschijnlijk ook dji (geven), en (2) verba die een richting-vanaf betekenen: komopo of komoto (komen vandaan), teki (nemen), puru (halen, trekken). Andere overeenkomstige verba als hari (trekken) geven geen richting aan en behoren hier dus niet toe ${ }^{2}$ ).

Alleen het verbum dat aan de plaatsbepaling vooraf gaat kan de richting van de handeling aangeven ${ }^{3}$ ). Wanneer dus de handelingseenheid bestaat uit de verba teki tjari (nemen dragen $=$ brengen) moet voor een plaatsbepaling nog het verbum go toegevoegd worden, als men een hande-

1) Onze informanten waren Richard Kapel en W. A. Sarucco. Verdere hulp werd verschaft door Mejuffrouw U. M. Lichtvel. D, wetenschappelijk ambtenaar aan de Universiteit van Amsterdam. Wij danken hen hierbij voor hun medewerking.

2) Op eenvoudige wijze zijn de richtingaanduidende verba te onderscheiden van andere verba: de andere verba kunnen namelijk alleen in combinatie met de genoemde verba een richting aangeven ten opzichte van een in de plaatsbepaling gegeven plaats. In een zin als:

mi har mi bruku go $t$ a $m$ kindi

ik trok m'n broek $\rightarrow$ tot aan mijn knieën

moet go toegevoegd worden om de richting aan te geven. hari (trekken) geeft dus op zichzelf geen richting aan.

3) In een zin als:

a e-go sen mi go na skoro

hij gaat zendt mij $\rightarrow$ bij school (= hij zal mij naar school zenden) geeft slechts het laatste verbum go de richting van de handeling aan. 
ling naar deze plaats toe wil uitdrukken. Deze toegevoegde verba hebben geen andere functie dan die van richtingaanwijzers. De handeling teki tjari go (nemen dragen gaan) betekent dus in zijn geheel: brengen $\rightarrow=$ brengen naar. Hierop volgt dan een in zichzelf statische plaatsbepaling. Een reeds nader beschreven structuurkenmerk ${ }^{1}$ ) vindt hier binnen de taalstructuur zijn verklaring. Het gebruik van richtingaanduidende hulpverba na het hoofdverbum is in de taalstructuur van het Sranan noodzakelijk, omdat de richting van de handeling ten opzichte van een bepaalde plaats niet door middel van voorzetsels kan worden uitgedrukt.

$2 b$. Naast de enkelvoudige plaatsbepalingen $d(r) a p e$ (daar) en dja of djaso (hier), vinden wij plaatsbepalingen met een bepalingsobject (substantief, substantiefgroep of pronomen). In dat geval moet een voorzetsel toegevoegd worden. De algemene plaatselijke relatie (in betekenis overeenkomend met het Nederlandse ,,bij”) wordt aangegeven door het voorzetsel $n a$. Men treft in het snelle spreken over het algemeen slechts de vormen $a$ (voor medeklinkers) en $n$ (voor klinkers) aan.

$a \quad k \quad$ a skoro $\left.{ }^{2}\right)$

hij gekomen $+\rightarrow$ bij school (= hij kwam naar school)

$a$ mop a skoro

hij gekomen $+\leftarrow$ bij school (= hij kwam van school)

na kan beschouwd worden als een basisvoorzetsel in plaatsbepalingen. Een plaatsbepaling zonder dit voorzetsel (uitgezonderd de enkelvoudige bepalingen dape en dja/djaso) is in principe niet mogelijk. De uitzonderingen op deze regel worden later behandeld.

$2 c$. De plaatselijke relatie tot een bepalingsobject kan nader gepreciseerd worden door toevoeging van ini (in), tapu (op), fesi (voor), baka (achter), mindri (midden, tussen), see (naast). Dit waren oorspronkelijk substantiva en nog vindt men als substantiva tapu (top), fesi (gezicht), baka (rug), mindri (midden), see (zijde) en, althans in oudere teksten, ook ini (binnenste) ${ }^{3}$ ). In constructies als na tapu tafra (op tafel) moet tapu

1) In een in het tijdschrift Lingua te publiceren artikel over het verbale systeem van het Sranan wordt beschreven het voorkomen van dergelijke hulpverba achter een hoofdverbum. $\mathrm{Zij}$ worden daar gevonden via hun onmogelijkheid om voor te komen in een vorm met prefix $e$-. Daar is tevens aangetoond, dat deze richtingaanduidende woorden behoren tot de klasse der verba.

$\left.{ }^{2}\right)$ Het teken ^ duidt aan, dat door samentrekking van meer lettergrepen de klinker twee toonkernen bezit (de enkele samengetrokken lettergreep heeft dezelfde intonatie als de lettergrepen waaruit die is samengetrokken; is er geen verschil in intonatie tussen de oorspronkelijke lettergrepen, dan vindt men de beide toonkernen niet): $k a<k o n$ na of kon $a$, mop $a<k o m o p o$ na of komopo a. De sluiting van de $\hat{\mathrm{m}}$ is in dit geval bovendien labiaal én velaar.

3) In de dagboeken van Johannes KING (een bosneger uit de stam der Matuari, levend in de laatste helft van de 19de eeuw) troffen wij aan: a hoso ini furu nanga buku 't huis inwendige vol met boeken ('t inwendige van het huis is vol met boeken), waar dus ini de kern is van een substantiefgroep, subject van de zin. 
echter een voorzetsel geworden zijn. Was dit woord in deze constructie een substantief, dan had het gevolgd moeten worden door $f u$ (van). a wan drai a bal skop a bal dirèk go $n$ in a gool hij wil draaien de bal schoppen de bal direct $\rightarrow$ in de goal $m$ wan kmoto na in Bakrakondre ik wil komen $+\leftarrow$ in Europa (=ik wil uit Europa vandaan gaan).

De precisering kan alleen in combinatie met het basisvoorzetsel na voorkomen.

$2 d$. De hier gegeven volgorde: $n a+$ precisering (bv. $i n i)+$ bepalingsobject, is alleen geldig wanneer het bepalingsobject een substantief of substantiefgroep is. Wanneer het bepalingsobject een pronomen of persoonsnaam is geldt de volgende woordorde: $n a+$ pronomen of persoonsnaam + precisering:

mi go wan her tra fasi nanga wan her tra stèlen

ik ging een heel andere wijze en een heel andere redenering

a masra Jan (of: en) tapu

bij meneer Jan ( hem) op (=ik ging op een heel andere manier en met een heel andere redenering op mijnheer Jan / hem af).

Deze waarschijnlijk nog wat te simplistisch gestelde regel wordt in paragraaf $3 a$ nader besproken aan de hand van een uitzondering.

2e. De plaatsbepalende voorzetsels kunnen geïntensiveerd worden door voorplaatsing van te (tot). Dikwijls wordt zo de subjectieve afstand waarover de handeling zich uitstrekt vergroot.

$d a$ har wan krois $t a$ mindr a san

dan hij trok een kruis tot bij midden 't ding ( $=$ dan zette hij een

kruis helemaal over het ding - een ingeleverd opstel - heen)

mi har mi bruku go $t$ a $m$ kindi

ik trok mijn broek $\rightarrow$ tot bij mijn knieën (= ik trok mijn broek helemaal tot mijn knieën op)

$a$ man ben-go $t$ a Vinezuela

de man was-gegaan $+\rightarrow$ tot bij Venezuela (= de man was helemaal naar Venezuela gegaan).

2f. Bij gepreciseerde voorzetsels kan het bepalingsobject weg blijven, als de situatie duidelijk genoeg is. Dit gebeurt nooit bij het ongepreciseerde voorzetsel $n a$.

a kan plei a fesi

hij kan spelen voor (= in de voorhoede)

den man di ben-d a ini

de mannen die waren erin ( $=$ in de club)

dat $m$ e-pot a tapu

dat ik stel boven (= boven alles)

$i \quad m$ jep $m$ krab en pur ala ferf a tapu

je moet helpen mij krabben hem halen $+\leftarrow$ alle verf op $(=$ je moet me helpen alle verf van hem - de fiets - af te krabben). 
$2 g$. Wij kunnen het voorgaande in het volgende schema samenvatten:

$\begin{aligned} & \text { handelingseenheid } \\ & \text { (met zo nodig aan- } \\ & \begin{array}{l}\text { duiding van richting } \\ \text { naar of van) }\end{array}\end{aligned}+\left\{\begin{array}{l}d(r) a p e, d j a(s o) \\ (t e+) n a+\left\{\begin{array}{l}\text { bepalingsobject } \\ \text { precisering } \\ \text { precisering }+\begin{array}{r}\text { substantief } \\ \text { (groep }\end{array} \\ \text { pronomen/naam }+ \text { precisering }\end{array}\right.\end{array}\right.$

Wij kunnen dus de volgende structuurregels opstellen:

(a) de plaatsbepalingen kunnen niet de richting van de daarop betrokken handeling uitdrukken;

(b) wanneer de plaatsbepaling gegeven wordt met behulp van een bepalingsobject moet gebruik gemaakt worden van het basisvoorzetsel na, al of niet vergezeld van een nadere precisering van de plaats;

(c) de precisering komt tussen na en substantiefgroep, of achter na en pronomen of persoonsnaam;

(d) alleen na gepreciseerde voorzetsels kan het bepalingsobject weg blijven;

(e) de voorzetsels kunnen alle voorafgegaan worden door een intensiveringswoordje te;

( $f$ ) andersoortige bepalingen (bv. tijdsbepalingen) kunnen niet door $n a$ worden voorafgegaan, ook niet in combinatie met preciserende voorzetsels.

3. - Na aldus de structuurregels of wetmatigheden in het kort geschetst te hebben, behandelen wij in deze paragraaf de uitzonderingen, waarover in de eerste paragraaf in algemene zin reeds werd gesproken. Het is ons niet mogelijk alle uitzonderingen te vermelden, maar wel kunnen wij de verschillende typen aan de hand van voorbeelden afzonderlijk bespreken.

$3 a$. Het eerste type kunnen wij voorlopig door gebrek aan materiaal niet anders behandelen dan als uitzondering op regel $c$. Wij vermoeden echter dat nader onderzoek zal uitwijzen dat regel $c$ aanvulling behoeft en dat dus dit type uitzondering wijst op een onvolledigheid in onze analyse en niet op een zwakte in de grammaticale structuur van het Sranan. Wij werden hier zeer gehandicapt door een tekort aan materiaal. Wij noteerden slechts twee voorbeelden van de woordorde: $n a+$ bepalingsobject + precisering. Een werd behandeld onder paragraaf $2 d$. Het andere voorbeeld was een afwijking:

man las den her koffisak a Arubagw a d Ama

mannen verlieten hun hele koffiezaak op Aruba gingen bij de vrouwen baka

achter (= gingen de vrouwen achterna)

$\mathrm{Bij}$ aanvullende experimenten bleek men steeds feilloos de plaatsbepalingen volgens regel $c$ te construeren. Wij kregen dus geen nieuwe uitzonderingen. Toch voelde men het bovenstaande voorbeeld niet algemeen als een fout. Er zijn zelfs aanwijzingen, dat er betekenisverschil bestaat tussen: a d Ama baka en a baka d Ama. Nader onderzoek kan dus aan het licht brengen, dat regel $c$ aanvulling behoeft.

West-Indische Gids XXXVII 
3b. Bij de voorzetselcombinatie na ini werd door één der proefpersonen in de meeste gevallen $(21 \times) n a$ weggelaten:

te $j$ de in a kool $j$ e-beefi sontron

als je bent in de goal je beeft soms

Buiten deze voorzetselcombinatie noteerden wij slechts het volgende voorbeeld:

a man e-mek bal psa mindr en futu

de man laat ballen passeren tussen z'n voeten

Dit voorbeeld is echter dubieus, omdat er slechts een gering verschil bestaat tussen psa mindr en futu en ps a mindr en futu (< pasa a mindri en $f u t u)$, dat ons licht kan zijn ontgaan. Wij willen daarom dit voorbeeld niet laten meetellen.

Het is opvallend dat alle afwijkingen van regel $b$ zich concentreren in de voorzetselcombinatie na ini. De proefpersoon weigerde aanvankelijk de afwijkingen te erkennen en hield zelfs bij de recorder vol dat hij na ini en niet $i n i$ alleen had gezegd. Zodra hij ook zelf de afwijking hoorde, stond hij erop, dat de ,,fouten" werden verbeterd in het afschrift. Structuurregel $b$ leeft dus wel in deze proefpersoon, hoewel hij hem bij het spreken gemakkelijk overtreedt, maar dan uitsluitend in de combinatie na ini. De andere proefpersoon kende deze afwijking niet.

3c. De hier genoemde voorzetsels en voorzetselcombinaties kunnen alleen in plaatsbepalingen optreden (zie regel $f$ ). Andere bepalingen worden gevormd zonder voorzetsels of met behulp van andere voorzetzels als nanga, $f u$, tegen, etc. Wij vonden op het gehele uitgebreide materiaal 11 duidelijke afwijkingen op deze regel, waarvan wij hier de overtuigendste voorbeelden tonen:

a no tjis a bal fu plei a en fas

hij niet kreeg de bal voor spelen op zijn wijze

$a$ ben-taig den man in $d$ eegi tongo

hij sprak-aan de mensen in hun eigen taal

De meeste voorbeelden vonden wij in de bepaling: in een taal.

in a span $f \quad a$ bal

in de spanning van de bal (nl. het balspel)

da $m j$ ab a wroko $a$ in $\hat{m}$ akti

dan ik heb 't werk in mijn macht

mi no rek a tap gwe

ik niet rekende op weggaan

Op de 11 genoteerde afwijkingen, waren er 8 in de voorzetselcombinatie na ini. In 9 van de 11 gevallen was er sprake van letterlijke vertaling uit het Nederlands.

$3 d$. Het voorzetsel ini vertoont van alle andere voorzetsels de grootste klank- en betekenisverwantschap met het Nederlandse voorzetsel ,,in". Het woord ini treft men in het huidige Sranan slechts zelden of nooit aan als substantivum (in de betekenis: binnenste, binnenkant). Alle andere specificerende voorzetsels komen in het huidige Sranan ook voor als substantivum (zie paragraaf $2 c$ ). Juist dit voorzetsel dus wordt het gemakkelijkste op de Nederlandse wijze gebruikt. In het huidige Sranan van Paramaribo worden vrij frequent Nederlandse woorden als: tegen, over, begrijpen, stelling, etc. gebruikt. Daarbij volgen zij echter de structuurregels van het Sranan. Een Nederlands verbum zal alleen 
in zijn stamvorm worden gebruikt en met de vereiste verbale prefixen gecombineerd worden $i$ n e-begrijp? ( = je niet begrijpt ?). Wanneer dus hier ini op Nederlandse wijze (dus volgens de Nederlandse structuurregels) wordt gebruikt, wil dit zeggen dat het gevoel voor enkele structuurregels van het Sranan verzwakt is. Dit wordt nog geaccentueerd doordat ook buiten ini enkele afwijkingen voorkomen. Er bestaan dus zwakke plekken in de structuur der plaatsbepalingen in het Sranan (vooral in de regels $b$ en $f$ ) en bij voortgaande invloed van het Nederlands zal men op deze punten veranderingen mogen verwachten.

\section{Het systeem der Pronomina Personale}

De Surinaamse Spraakkunst, die pater DonICIE onlangs heeft doen verschijnen ${ }^{1}$ ), stelt de onderzoekers voor verrassende problemen. Oude en gevestigde theorieën worden hier weggeslagen met een durf, die verkwikkend is. Men weet, dat sinds lang het lidwoord $d a$ als een kunstmatige, literaire vorm der zendelingen werd beschouwd. Een mening, die eendrachtig werd gedeeld door Lichtveld, Simons, Donicie en mij. Hiertegenover kiest DoniCIE plotseling stelling (p. 141): ,We zijn thans van mening, dat dit vermoeden ongegrond is". En inderdaad, er zijn teveel feiten bekend geworden (meer nog dan DoNicIE hier noemt), die de vroegere theorie onwaarschijnlijk maken.

Deze vroegere theorie heeft echter het voordeel een theorie te zijn, dat wil zeggen een verklaring te geven. DoNICIE neemt ons een heldere en plausibele verklaring uit handen, zonder er iets voor in de plaats te stellen. Wij worden opnieuw voor een probleem gesteld, dat jaren geleden al tot ieders genoegen scheen opgelost. En dit gebeurt in deze spraakkunst bij herhaling. Overal komt pater DonICIE met nieuwe feiten, die niet blijken te passen in de traditionele taalbeschrijving. Hij heeft een ware ravage aangericht in het Surinaamse taaltuintje en er een fris, maagdelijk oerwoud van gemaakt.

Dit is een daad van groot belang, die slechts verricht kon worden door iemand die zich met scherpzinnigheid vrij wist te houden van vooropgezette meningen. Voor velen zal zijn werk irritant zijn, omdat het zoveel onrust brengt (soms ook geheel onnodig) en zo weinig positieve oplossingen geeft. Maar juist hierdoor zal het een buitengewoon vruchtbaar werk blijken, dat op vele terreinen.tot nieuw onderzoek prikkelt. Ik heb gemeend van mijn sympathie voor deze spraakkunst niet beter te kunnen getuigen, dan door nauwkeurig verslag te doen van een klein onderzoek, waartoe dit boek van DoNICIE mij voerde.

1) A. Donicie: De Creolentaal van Suriname, Spraakkunst. Paramaribo, 1954. 
In hoofdstuk VII bespreekt pater DoNICIE de persoonlijke voornaamwoorden. Hij geeft hiervan het volgende overzicht:

\begin{tabular}{|c|c|c|l|}
\hline & re pers. & ze pers. & 3e pers. \\
\hline$S g$. & $\mathrm{mi}$ & $\mathrm{ju}, \mathrm{i}$ & $\mathrm{a}, \mathrm{en}$ \\
\hline$P l$. & wi, unu, un & unu, un & den \\
\hline
\end{tabular}

In tekst en noten brengt hij verdere nuances aan:

$1 a$ (3e pers. sg.) komt uitsluitend als subject voor,

2 het verschil tussen $a$ en $e n$ als subject kan niet altijd duidelijk worden aangegeven : $e n$ bij emphase, $a$ meestal als zgn. $4 \mathrm{e}$ pers. in de afhankelijke zin (dwz. een andere $3 e$ pers. aanduidend dan het subject van de hoofdzin),

3 meestal $w i$ als 1e pers. pl., unu, un en soms ook $u$ als 2e pers. pl.,

4 volgens Lichtveld (zijn mening werd in een noot door Donicie meegedeeld) noemt $w i$ de aangesprokenen inclusief de spreker, un de aangesprokenen in- en exclusief de spreker ${ }^{1}$ ),

5 ook $w i$ treedt soms op (twee voorbeelden worden meegedeeld) als 2e pers. pl.

Hiermee hebben wij het probleem, dat ons in dit artikel verder zal bezighouden, duidelijk voor ogen: $w i$, unu en $u n$ kunnen zowel in de le als 2e pers. pl. gebruikt worden, terwijl Donicie toch redenen schijnt te hebben beide categorieën te blijven onderscheiden. Wanneer zijn constateringen juist zijn, dan moet er ò geen onderscheid bestaan tussen $1 \mathrm{e}$ en $2 \mathrm{e}$ pers. pl., of er moet een ander, ons nog onbekend onderscheid bestaan, dat niet samenvalt met het Europese. Suriname schijnt in beide gevallen verder te liggen van Europa dan men dacht; wat natuurlijk niet impliceert, dat het dus in Afrika moet liggen ${ }^{2}$ ).

1) Om eenheid in terminologie te bewaren zet ik deze mening om in de meer gebruikelijke termen 1e pers. pl. inclusivum (= inclusief de aangesprokene) en exclusivum (= exclusief de aangesprokene). - Deze mening van LichtVELD laat de voornaamste problemen onbesproken, namelijk 1. Welke vorm wordt gebruikt voor de le pers. pl. exclusivum? 2. Bestaat er onderscheid tussen inclusivum en exclusivum? 3. Bestaat er onderscheid tussen $w i$ en $u n$ als le pers. pl. inclusivum.

2) De Afrikacentrische taalbeschouwing, waar LichtVELD nog onlangs een pleidooi voor hield (Enerlei Creools? W. I. Gids 35, 1954, p. 59-70), is even uitzichtloos als de traditionele Europacentrische en voert onvermijdelijk tot nieuwe fouten. De geschiedenis van de (Europese) linguistiek heeft ieder linguist overtuigd van de fatale invloed van ieder a-priori op de taalanalyse. Men dient iedere taalvorm in de gegeven taal alleen te onderzoeken, zonder vooraf bepaalde verwachtingen omtrent de uitkomst te koesteren, Afrikaanse noch Europese, noch mogelijk universeelCreoolse. 
Interessant is het, naast deze constateringen van DoNicIE, de analyse van HALL te plaatsen ${ }^{1}$ ). HALL beschrijft het volgende systeem:

\begin{tabular}{|c|c|c|c|c|}
\hline & \multirow{2}{*}{ Ie pers. } & \multirow{2}{*}{$2 e$ pers. } & \multicolumn{2}{|c|}{$3 e$ pers. } \\
\hline & & & subj. & $o b j$. \\
\hline Sg. & $\mathrm{mi}$ & \multirow{2}{*}{ ju, unu } & a-, en & en \\
\hline Pl. & wi & & d & \\
\hline
\end{tabular}

Juist in de le pers. pl. schijnen zich geen moeilijkheden voor te doen. HALL is dus nooit gestuit op de vorm $u n(u)$ in de le pers. pl. Verder valt ons op het gebrek aan onderscheid tussen 2 e pers. sg. en pl.

Deze analyse werd door mij op dezelfde teksten herhaald. ${ }^{2}$ ) De resultaten verschilden zeer. Ik meen echter ook de oorzaak van dit verschil te kunnen aantonen. HALL heeft op het materiaal van HERSKovits vertrouwd, ook waar critiek mogelijk was. Zo heeft HaLL het duidelijk bestaande onderscheid tussen 2e pers. sg. en pl. verwaarloosd op grond van het feit, dat hij $6 \times$ de vorm $j u$ noteerde voor de $2 \mathrm{e}$ pers. pl.; hoewel hij nooit de vorm $u n(u)$ in het enkelvoud heeft ontmoet. De door Herskovits genoteerde vorm $j u$ in de $2 \mathrm{e}$ pers. pl. komt nooit voor, zoals HaLL had kunnen vernemen van zijn informant, Dr. EINAAR, die de teksten voor hem interpreteerde. In drie der gevallen kwam bij Herskovirs de vorm $j u$ voor na $i$, waardoor de $j$ als overgangsklank begrepen kan worden. Het pronomen personale was daar $u$.

Hall heeft verder de vorm $u n(u)$ in de le pers. pl. alleen over het hoofd gezien, omdat hij vertrouwde op de Engelse vertaling van HersKovirs. Herskovits vertaalde deze vorm namelijk consequent als een $2 \mathrm{e}$ pers. pl., ook wanneer uit de tekst duidelijk bleek, dat men met een le pers. pl. te doen had. De gesignaleerde fouten zijn dus grotendeels toe te schrijven aan het vertrouwen, dat HALL in materiaal èn vertaling van HersKovits heeft gesteld.

Het resultaat van mijn analyse was (alleen voor het meervoud) zoals de tabel op volgende bladzijde aangeeft.

Zoals men ziet heb ik een onderscheid gemaakt tussen het pronomen personale als subject van de zin en voor een nomen (possessief gebruik), èn dit pronomen als object van de zin en na een voorzetsel. De ter plaatse ingevulde cijfers duiden de aantallen genoteerde getallen aan. Dit is noodzakelijk, wil men bijvoorbeeld zien, dat het onderscheid tussen inclusivum en exclusivum in het object slechts op 9 gevallen werd gebaseerd. Ik deel

1) Robert A. Hall Jr: The Linguistic Structure of Taki-Taki. Language 24, 1948, p. 92-116.

2) Melville J. Herskovits \& Frances S. Herskovits: Suriname Folk-Lore. With Transcriptions and Musicological Analysis by M. KolinSKI. New York, 1936. Slechts het materiaal van hun informanten no. 3 en 10 werd niet onderzocht. De een is van Javaanse afkomst, de ander leefde lange tijd onder de bosnegers. 


\begin{tabular}{|c|c|c|c|c|}
\hline & $\begin{array}{c}\text { Ie pers. } \\
\text { exclusivum }\end{array}$ & $\begin{array}{c}\text { I } \text { p pers. } \\
\text { inclusivum }\end{array}$ & 2e pers. & 3e pers. \\
\hline $\begin{array}{c}\text { subject } \\
\text { (ook als } \\
\text { possessief } \\
\text { voor nomen) }\end{array}$ & $\begin{array}{c}w i \\
(19 \times)\end{array}$ & $\begin{array}{c}w i \\
(24 \times)\end{array}$ & $\begin{array}{c}\text { un } \\
(44 \times)\end{array}$ & den \\
\hline $\begin{array}{c}\text { object } \\
\text { (ook na een } \\
\text { voorzetsel) }\end{array}$ & $\begin{array}{c}w i \\
(5 \times)\end{array}$ & $\begin{array}{c}\text { un } \\
(4 \times)\end{array}$ & $\begin{array}{c}u n \\
15 \times)\end{array}$ & den \\
\hline
\end{tabular}

dit resultaat dan ook met grote reserve mee. Vooral ook omdat ik twee uitzonderingen heb genoteerd in de teksten van Herskovits: eenmaal werd un gebruikt als le pers. pl. exclusivum object, eenmaal als le pers. pl. inclusivum subject. Het gegeven schema is dus tendentieus en suggereert meer dan bewezen kan worden.

ForCHHEIMER ${ }^{1}$ ) ziet het personale systeem beheerst door de tegenstelling subjectiviteit-objectiviteit. De meest subjectieve categorie is de le pers. sg. De le pers. pl. is duidelijk objectiever. De meest objectieve daarvan is het inclusivum, vooral als object van de zin. Er is dus een overgang naar het meer objectieve van de le pers. pl. exclusivum subject naar de $2 \mathrm{e}$ pers. pl. subject. Een nieuwe vorm kan gebezigd worden en dus een nieuwe categorie ontstaan bij de $2 \mathrm{e}$ pers. pl. subject (zoals in de Europese talen), maar even goed bij de le pers. pl. inclusivum object.

In dit stadium van het onderzoek moest ik informanten te hulp roepen ${ }^{2}$ ), om op groter materiaal te kunnen nagaan of inderdaad de uit HERSKovits' teksten naar voren gekomen tendens, in het Sranan bestond. Ik werd geholpen door twee Surinamers, uiteraard in Nederland woonachtig, voor wie het Sranan moedertaal is en die ook tijdens hun verblijf in Nederland dagelijks deze taal zijn blijven gebruiken. Men zal uit hun informatie een beeld krijgen van het Sranan, zoals dat onder de jongere arbeiders van Paramaribo wordt gesproken. Ik beschrijf hier dus het systeem der pronomina personale van deze beide informanten en niet de ongetwijfeld veelzijdige mogelijkheden binnen dit systeem in het gehele Surinaamse taalgebied.

Het resultaat van de gesprekken met deze informanten was na het voorgaande verrassend.

Allereerst gebruikten zij nooit de vorm wi, ook niet bij een langzaam spreektempo. Ik noteerde slechts de vormen $u$, un en $u n u$ in $1 \mathrm{e}$ en $2 \mathrm{e}$ pers. pl. Alle $w i$-vormen bij Herskovirs werden spontaan verbeterd in $u$, un of $u n u$. Het is natuurlijk ondenkbaar, dat Herskovits wi en un met elkaar verwisselde. Hieruit zou men daarom willen concluderen, dat de vorm wi

1) Paul Forchhermer: The Category of Person in Language. Berlin, 1953.

2) De mogelijkheid goede informanten aan te trekken werd mij geboden door WOSUNA in verband met een opdracht van wijder strekking. Zie ook de voetnoten op p. 192 en 194. 
uit de taal der Surinaamse arbeiders is verdwenen in de loop der jaren. Men kent de vorm $w i$ wel, verstaat hem ook, maar gebruikt hem zelf nooit.

De tweede verrassende ontdekking was, dat door mijn informanten geen onderscheid werd gemaakt tussen $1 \mathrm{e}$ en $2 \mathrm{e}$ pers. pl. De vormen $u, u n$ en $u$ u $u$ werden zowel in de $1 \mathrm{e}$ als $2 \mathrm{e}$ pers. pl. gebruikt.

Een der informanten werd door dit gebrek aan onderscheidingsmiddel af en toe danig in verlegenheid gebracht. Men moet bedenken, dat hij tijdens de zittingen gebracht werd tot taalgebruik los van de normale gesprekssituatie. Ik heb hem wel steun gegeven, door in een uitvoerig gesprek de bedoeling van de zin zo duidelijk mogelijk te doen zijn. Dat neemt niet weg, dat hij zich langzamerhand uit mijn vragen vaag bewust werd van de onmogelijkheid beide Nederlandse categorieën in het Surinaams te onderscheiden.

Toen hij dus in een bepaalde situatie moest reageren met un moni (= jullie geld) en zich daarbij door voorgaande besprekingen verwarrend bewust werd van het feit, dat ditzelfde ook ,,ons geld" zou kunnen betekenen, toen voegde hij er snel aan toe: eigenlijk heb ik dat geld ook een beetje als van mijzelf beschouwd. Toen hij kwam te spreken over de kinderen van een echtpaar, richtte hij zich alleen op de moeder der kinderen en sprak van den ptjin $f j u$ (= de kinderen van jou). Hij wilde hier liever niet de vorm unu gebruiken.

Deze weifeling kwam natuurlijk nog duidelijker naar voren, toen ik hem, in het laatste gesprek over dit onderwerp, voor situaties plaatste, waarin hij in dezelfde zin de 1e en 2e pers. pl. tegenover elkaar moest stellen. Hij deed dit door hetzelfde woord (un) te gebruiken, verduidelijkt met gebaren: bijvoorbeeld, $A$ man no dji $\rightarrow$ un sjen, ma na un $\leftarrow$ a $g$ a sjen ( = de man niet gaf jullie schaamte, maar ' $t$ is ons hij gaf de schaamte). Dikwijls ook verving hij le of $2 \mathrm{e}$ pers. pl. door een enkelvoud, om duidelijker het verschil te laten uitkomen. Zo vertaalde hij eerst de zin: „Wij hebben het niet gedaan, maar jullie", met $A$ no mi du en, a un du en. Toen ik hem wees op de onnauwkeurige vertaling, verbeterde hij het in: A no un du en, a ju du en. Soms ook vertaalde hij op eigen gezag beide personen in het enkelvoud, waar meervoud gevraagd werd, bijvoorbeeld: Den ptjin $f$ ju tranga jesi, ma du f mi e-jere wantron (= de kinderen van jou hard gehoor, maar die van mij luisteren dadelijk) ${ }^{1}$ ).

De andere informant zag na enige tijd duidelijk de onmogelijkheid le en 2e pers. pl. in het Surinaams te onderscheiden, maar had hieraan ook geen behoefte in het normale contact. Pas toen hij beide personen in dezelfde zin moest onderscheiden begon hij te aarzelen. Hij gebruikte eerst wi tegenover unu. Duidelijk was echter te merken, dat dit hem niet bevredigde. Hij gaf dan ook dadelijk toe zo niet tegen zijn moeder te spreken. Na nog enige aarzeling gebruikte hij beide keren $u n$. Ook hij toonde dikwijls de neiging één van beide tegenover elkaar gestelde personen door een enkelvoud te vervangen.

Wij zijn dus tot onze verrassing gedwongen de vormen $u$, un en unu $(1 \mathrm{e}+2 \mathrm{e}$ pers. pl.) te zien als drie structureel irrelevante varianten ter

1) Door slechts één van beide informanten werd den di fu mi samengetrokken tot den $d u f m i$. Zie voor de notering der samentrekkingen de volgende voetnoot. 
aanduiding van een groep personen waaronder spreker en/of aangesprokenen. Hiertegenover staat in het meervoud de vorm den (3e pers. pl.) ter aanduiding van een groep personen zonder de spreker of aangesprokenen.

Ons rest nu nog slechts uit te maken onder welke omstandigheden de verschillende varianten gebruikt kunnen worden. Wij kunnen $u$ en $u n$ beschouwen als meer of minder ver doorgevoerde verkortingen van $u n u$. De volle vorm unu kan steeds optreden, maar wordt om ritmische redenen dikwijls vermeden. Men vindt unu meest op het zinseinde of voor een duidelijke pauze. Het is echter ook mogelijk in zulke gevallen un te gebruiken.

De vorm $u$ of bilabiale $w$ kwam bij mijn informanten zeer veel voor. Wij vonden deze vorm meestal voor $n$ en voor of na een klinker. Wij zullen hiervan uit het materiaal enkele voorbeelden geven ${ }^{1}$ ).

\section{Voor een klinker}

1 Voor verbaal prefix $e-$ :

San $w$ e-frede? (Wat jullie zijn-bang ?)

$W$ e-pot en dji usrefi. (Wij stoppen hem geven ( = in) onszelf)

Ef i no taig un, $w$ e-go tjir i. (Als je niet vertelt ons, wij gaan doden je)

Te $w$ e-du wan sani, $u$ n e-kba. (Als jullie doen een ding, jullie niet eindigen)

2 Voor $a$ :

Den wan or $w$ a spotu. (Zij willen houden ons voor spot)

A sa-du $w$ ala. (Het zal-gebeuren ons allen)

A s a i-psa nanga $w$ ala. ('t-Is zo het gebeurt met ons allen)

Gado dji $w$ ala wan sani. (God gaf ons allen één ding)

\section{Na een klinker}

$1 \mathrm{Na} a$ :

Na $u$ trefu. ('t Is onze treef)

Sa $u$ sa-du dan? (Wat wij zullen-doen dan)

Da $u$ bj-a wan tra sani. (Dan wij hadden een ander ding)

$2 \mathrm{Na} o$ :

Ko $u$ gwe. (Laat ons weggaan)

$3 \mathrm{Na} e$ :

Den sma aks un pe $w$ kmoto. (De mensen vroegen ons waar wij vandaankwamen)

\section{Voor $n$}

$U \mathrm{n}$ a f rede. (Jullie niet hebben om-te vrezen = wees niet bang) $U$ no mandi nang en. (Jullie niet vertoornen op hem)

1) Wij hebben ons gehouden aan het spellingsvoorstel van Prof. WiLLEM Pée, Prof. W. Gs. Hellinga en A. Donicie (zie de bijlage in de Spraakkunst van DoNicIE). Door lettertekens weg te laten en de verlenging aan te geven door een punt boven de lijn achter het betreffende letterteken, hebben wij getracht in deze voor literair gebruik geschapen spelling toch de samentrekkingen op duidelijke wijze aan te geven. 
$U$ no kan jepi. ( $W i j$ niet kunnen helpen)

$U$ no sji noti. (Wij niet zagen niets)

A man no aks $u$ noti. (De man niet vroeg ons niets)

$U$ no fet moro. (Jullie niet vecht meer $=$ vecht niet meer)

Een enkele keer kwam $u$ ook buiten deze gevallen voor tijdens het interview. Enige variatie is natuurlijk altijd mogelijk, wanneer het verschil tussen de vormen niet structureel is. Zo kan men verklaren, dat mijn informanten in de voorbeelden van DoNICIE de vorm un dikwijls veranderden in $u$. Zo zeiden zij steeds Olat $u$ de ? (Hoelaat wij zijn $=$ hoelaat is het). $\mathrm{Zij}$ gebruikten hier zelfs liever niet de volle vorm unu, omdat men de zin dan zou kunnen begrijpen als: „Hoelaat zijn jullie er ?”' Ook gebruikte dezelfde informant in dezelfde zin dikwijls nu eens $u n$, dan weer $u$, zonder verschil in betekenis.

Het hierboven beschreven onderzoek stelt ons in staat de presentatie van het feitenmateriaal van DoNICIE belangrijk te vereenvoudigen:

\begin{tabular}{|c|c|c|c|c|}
\hline & Ie pers. & 2e pers. & \multicolumn{2}{|c|}{ 3e pers. } \\
\cline { 3 - 4 } & subject & object \\
\hline$S g$. & $\mathrm{mi}(\mathrm{m})$ & ju (i) & a, en & en \\
\hline$P l$. & \multicolumn{2}{|c|}{ unu (un, u) } & \multicolumn{2}{|c|}{ den } \\
\hline
\end{tabular}

De door Donicie gegeven voorbeelden van de vorm $w i$ in de $2 \mathrm{e}$ pers. pl. werden ten dele al in de hierboven gegeven voorbeelden verklaard. DONICIE had namelijk de bilabiale $w$ voor $e$ geïnterpreteerd als een verkorting van wi. Een ander voorbeeld mi n e-go njan wi (Ik niet ga opeten jullie $=\mathrm{ik}$ zal jullie niet opeten) kon niet aldus verklaard worden. Een excessieve verkorting tot mi no.nja $w$ wordt tenslotte begrepen door de informanten, maar niet spontaan gebruikt. Ik heb mij daarom afgevraagd of DonICIE's informant niet gezegd kan hebben: wi ne go njan wi (wij zullen elkaar niet opeten) ? In de context past dit heel goed.

Men zal uit dit artikel gelezen hebben, dat men het zeker niet overal eens behoeft te zijn met de spraakkunst van pater DoNicie, om toch met volledige sympathie te blijven staan tegenover zijn werk. Donicie verklaart weinig, zijn boek zit dan ook vol met ruw, onbewerkt materiaal. Hij is echter een man, die in Suriname niet heeft gehoord wat hij graag zou willen horen, maar de kunst verstaat objectief het taalgebruik te observeren, en elk waargenomen feit te registreren, ook al schijnt het hem onlogisch en onverklaarbaar.

\section{De Bouw van de Substantiefgroep}

Het is opmerkelijk, dat over het verbale systeem van het Sranan uitvoerige studies geschreven worden, maar over de bouw van de substantiefgroep slechts twee opmerkingen worden 
gemaakt: men wijst op de mogelijkheid van een bepalend (de bezitter-aanduidend) substantief voor het bepaalde substantief en op het pronomen demonstrativum achter het bepaalde substantief. Slechts pater DONICIE is in zijn grammatica verder gegaan ${ }^{1}$ ), maar ook hij heeft de bouw van de substantiefgroep niet systematisch onderzocht.

Dit is opmerkelijk, maar ook zeer begrijpelijk. In het verbale systeem doet het Sranan zich voor als een typisch buitenEuropese taal. Het verbale systeem wordt niet begrepen en daarom ijveriger bestudeerd. De substantiefgroep lijkt volkomen op Europese wijze gebouwd. De Europeaan zal doorgaans geen grove fouten maken, wanneer hij de substantiefgroep in het Sranan op de hem vertrouwde wijze bouwt. Doorgaans niet, omdat hij zich gewoonlijk tevreden stelt met zeer eenvoudig gebouwde woordgroepen. In het normale taalgebruik van Surinamers zal hij ook węinig opmerkelijks ontdekken, want ook de Surinamer vermijdt ingewikkeld gebouwde woordgroepen. Dat de structurele mogelijkheden veel gecompliceerder zijn zal uit het vervolg blijken.

Eenvoudige theoretische redenering toont al, dat de afwijkingen van de Nederlandse substantiefgroep groter moeten zijn dan over het algemeen wordt aangenomen. Het Sranan kent geen flectie-uitgangen en kan dus moeilijk onderscheid maken tussen een aardige versierde kamer en een aardig versierde kamer. Dit onderscheid moet dus op geheel andere wijze in het Sranan verwoord worden. Maar over het geheel genomen lijkt de substantiefgroep in het Sranan bijzonder veel op die in het Nederlands.

Deze opvallende gelijkenis is gevaarlijk voor de taalbeschrijver. Immers, hij veronderstelt dingen bekend, die nog allerminst gekend zijn. Wij weten nog vrijwel niets van de bouw van de Nederlandse substantiefgroep. En bovendien wordt zijn aandacht niet door taalmoeilijkheden gericht op problemen, die hier zouden kunnen schuilen.

Een taal zonder flectie stelt de onderzoeker altijd voor bijzondere problemen. De functie van een woord wordt namelijk niet kenbaar gemaakt aan de woordvorm (door middel van de uitgang), maar op dikwijls veel ingewikkelder wijze door middel van de combinatiemogelijkheden met andere woorden, de plaats in de woordgroep of de intonatie. Dit maakt het structurele onderzoek tijdrovender, ingewikkelder. Omdat nog zo dikwijls een taal zonder flectie synoniem wordt geacht aan een taal zonder structuur en daarom ook het structurele onderzoek van zulk een taal niet wordt begrepen, demonstreren wij hier het onderzoek en daarmee de taalstructuur uitvoeriger dan strikt noodzakelijk is.

Wij gaan uit van een woordgroep als:

wan moi grun ati

een mooie groene hoed

1) A. Donicie: De Creolentaal van Suriname. Spraakkunst. Paramaribo, 1954. 
en trachten met behulp van informanten andere combinatiemogelijkheden te vinden door: $(a)$ een woord uit deze groep te vervangen door andere woorden, $(b)$ andere woorden tussen de woorden uit deze groep te plaatsen, (c) de woorden uit deze groep van plaats te laten wisselen. De informanten moeten verklaren of het goed Sranan is of niet, of dus de nieuwe combinatie mogelijk is of niet. Bovendien liet ik de informanten een vertaling geven in het Nederlands of een omschrijving in het Sranan. Dit laatste is noodzakelijk, wanneer men werkt met weinig gevormde informanten, die een functie- of betekenisverandering van de gebruikte woorden niet plegen op te merken, wan eerste-klas dot wroko (een bijzonder vuil werk) is goed Sranan, eerste klas is echter geen bepaling van wroko, maar van doti. Zonder vertaling of omschrijving zou men foutieve conclusies op een dergelijk voorbeeld kunnen baseren.

De eerste proef met informanten levert bijvoorbeeld de volgende afgekeurde combinatie op: *wan grun moi ati (een groene mooie hoed). Blijkbaar bestaat er een dwingende volgorde tussen bepalingen van het type grun (dichter bij het substantief) en moi (verder van het substantief). Andere kleurbepalingen vallen in dezelfde categorie als grun. Dit leert ons een hele reeks proefzinnen. Bij een poging de grenzen van deze categorie te bepalen stuiten wij op de woordgroep: wan moi spanjoro uma (een mooie Spaanse vrouw). Ook moi en spanjoro zijn niet om te wisselen, en dus zou men zeggen dat ook de nationaliteitsbepalingen binnen de categorie grun vallen. Deze voorlopige conclusie wordt te niet gedaan door de woordgroep: wan blaka spanjoro uma (een zwarte Spaanse vrouw). Wij experimenteren verder om andere eigenschapswoorden tussen kleur- en nationaliteitsbepalingen of na de nationaliteitsbepalingen in te voegen. Andere eigenschapswoorden komen altijd voor de kleur-en nationaliteitsbepalingen te staan.

Hiermee hebben wij de volgende structuurregels gevonden:

$I$ voorbepalingen van de eerste graad $^{1}$ ) noemen de nationaliteit van het bepaalde substantief.

2 voorbepalingen van de tweede graad noemen de kleur van het bepaalde substantief.

3 voorbepalingen van de derde graad noemen de andere eigenschappen van het bepaalde substantief.

Wanneer wij nu verder experimenteren blijkt het niet mogelijk meerdere andere eigenschappen van het bepaalde substantief te noemen. Het is alleen mogelijk de nationaliteit, de kleur en éen eigenschap van het substantief te noemen. wan takru broko oto (een lelijk gebroken auto) behoort wel tot de structurele mogelijkheden, maar dan bepaalt het voorgaande het volgende eigenschapswoord en niet het substantief.

1) Het heeft geen zin in dit stadium van het onderzoek termen uit de traditionele grammatica te introduceren. Voorbepalingen zijn bepalingen van een substantief, die voor het bepaalde substantief geplaatst worden. De verschillende voorbepalingen worden geteld vanaf het substantief dat zij bepalen. Voorbepalingen van de eerste graad zijn dus bepalingen die (als zij gebruikt worden) onmiddellijk voor het substantief staan.

Men zal wellicht opmerken, dat wij stofbepalingen $(u d u=$ houten, $i s r i=$ ijzeren, etc.) niet in het overzicht hebben opgenomen. Op dit punt schijnen nog niet alle problemen opgelost. De stofbepalingen komen soms na, soms voor de nationaliteitsbepalingen. 
Wij kunnen dit als volgt formuleren:

4 de eigenschapswoorden voor voorbepalingen van de derde graad be-

palen deze voorbepaling nader.

Bij verder experimenteren komt aan het licht, dat nog enkele woorden tussen de gevonden categorieën geplaatst kunnen worden:

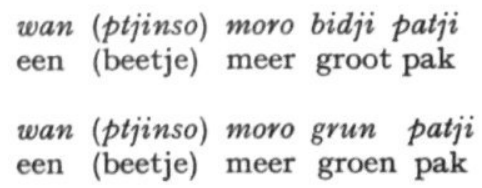

Een nationaliteitsbepaling kan echter niet nader bepaald worden door moro. Eveneens onmogelijk blijkt een woordgroep als:

*wan bidji moro grun patji

een groot meer groen pak

Wel mogelijk blijkt:

wan tra moro switi redi bromtji de

een ander meer zoet rood bloemetje is-er

Uit deze voorbeelden zijn de volgende structuurregels te destilleren:

5 alleen de voorbepalingen van de tweede en derde graad kunnen nader bepaald worden door (ptjinso) moro.

6 voorbepalingen van de tweede graad kunnen alleen nader bepaald worden door (ptjinso) moro wanneer geen voorbepaling van de derde graad vooraf gaat.

Het heeft geen zin op dezelfde uitvoerige (maar toch nog lang niet volledige wijze) te demonstreren hoe de verdere categorieën gevonden werden. Wij vertrouwen dat de in wezen zeer eenvoudige methode van structureel onderzoek na het voorgaande duidelijk genoeg geworden is. Door middel van taalexperimenten met behulp van informanten worden de taalcategorieën gevonden. Soms lijkt deze methode omslachtig, wanneer bijvoorbeeld de informanten reeksen proefzinnen worden voorgelegd, die alle moeten bewijzen dat een bepaalde constructie niet mogelijk is. Men zou rechtstreeks zonder voorbeelden naar de structuur willen informeren. De taalstructuur echter leeft onbewust in de taalgebruikers, zij bouwen hun constructies automatisch op. Ook in de eigen taal kan men alleen met behulp van experimenten de structuur ontdekken.

Wij formuleren nu in het kort de overige structuurregels, die wij hierna in een schema samenvatten:

7 tra (ander) is een voorbepaling van de vierde graad: 1) wan tra moi sani (een ander mooi ding).

8 de voorbepaling van de vierde graad (tra) kan alleen door middel van heri (heel) nader bepaald worden: wan her tra sani (een heel ander ding) 9 voorbepalingen van de vijfde graad bevatten woorden van het type

1) Wij vonden in deze categorie geen andere woorden dan tra, wat niet wil zeggen dat er geen andere woorden te vinden zouden zijn. 
enkri (enkel), fosi (eerste), srefi (zelfde), etc.: nowan enkri tra sani (geen enkel ander ding).

Io voorbepalingen van de zesde graad bevatten de telwoorden: den furu srefi oso (de vele zelfde huizen, huizen van hetzelfde type).

$I I$ voorbepalingen van de zevende graad bevatten de artikels: $a$ wan brara $f u m i$ (de ene broer van mij).

I2 bij voorbepalingen van de zesde en zevende graad moet men scheiding maken tussen singulare en plurale bepalingen.

I3 alleen het plurale artikel kan voorafgegaan worden door ala (alle).

I4 zowel bij de singulare als plurale voorbepalingen van de zesde graad vindt men telwoorden, die niet door een artikel voorafgegaan kunnen worden: omen oso $j u$ abi (hoeveel huizen heb je), ibriwan guduman (iedere rijkaard).

I5 de voorbepalingen van de zevende graad kunnen vervangen worden door het pronomen personale: mi furu moi krosi (mijn vele mooie kleren).

I6 de voorbepalingen van de zesde graad kunnen vervangen worden door een bepalende substantiefgroep: ala mi m̌a dri ati priti (al mijn moeders drie hoeden zijn-gescheurd) ${ }^{1}$ ).

$I 7$ alleen bepaalde telwoorden kunnen na een bepalende substantiefgroep gebruikt worden (zie het voorbeeld onder 16).

I8 achterbepalingen van de eerste graad worden gevormd door de pronomina demonstrativa: den dri fooru dati (de drie kippen die $=$ die drie kippen).

I9 een achterbepaling van de eerste graad kan slechts voorkomen als ook een artikel (voorbepaling van de zevende graad) of het telwoord wan (voorbepaling van de zesde graad) gebruikt wordt.

20 er zijn vier soorten achterbepalingen van de tweede graad: a) een groep woorden van het type srefi, b) een bepaling met $f u, \mathrm{c})$ een bijzin

\begin{tabular}{|c|c|c|c|c|c|c|c|c|c|c|}
\hline \multirow[t]{3}{*}{8} & 7 & 6 & 5 & 4 & 3 & 2 & 1 & & 1 & 2 \\
\hline & & $\begin{array}{l}\text { sowan } \\
\text { nowan } \\
\text { iniwan } \\
\text { ibri(wan) }\end{array}$ & \multirow{2}{*}{$\begin{array}{l}\text { enkri } \\
\text { fosi }\end{array}$} & \multirow{5}{*}{ tra } & \multirow{5}{*}{ 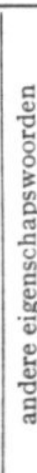 } & \multirow{5}{*}{ 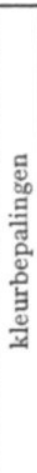 } & \multirow{5}{*}{ 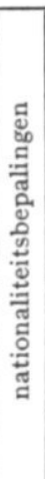 } & \multirow{5}{*}{ subst. } & \multirow{5}{*}{ disi } & $\begin{array}{l}\text { srefi } \\
\text { Wan } \\
\text { dape } \\
\text { so }\end{array}$ \\
\hline & a & wan & & & & & & & & \\
\hline \multirow{3}{*}{ ala } & & $\begin{array}{l}\text { telwoord } \\
\text { wan }\end{array}$ & \multirow{3}{*}{$\begin{array}{l}\text { srefi } \\
\text { sèm }\end{array}$} & & & & & & & 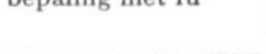 \\
\hline & den & $\begin{array}{l}\text { wantu } \\
\text { somen } \\
\text { furu } \\
\text { nofo }\end{array}$ & & & & & & & & bijzin met di \\
\hline & & $\begin{array}{l}\text { omen } \\
\text { son }\end{array}$ & & & & & & & & bijzin zonder voegw. \\
\hline
\end{tabular}

1) Deze bepalende substantiefgroep kan de bezitter van het bepaalde substantief aangeven (zoals in het gegeven voorbeeld), maar ook een hoeveelheidsbepaling aangeven: wan er ipi moi sani (een hele hoop mooie dingen), tu preti switi tjiknfrainrais (twee schotels lekkere chicken-friedin-rice). 
ingeleid door $d i, \mathrm{~d})$ een bijzin zonder voegwoord: den fooru disi srefi (de vogels deze zelf $=$ deze vogels zelf), den foor $u$ disi fu mi (deze vogels van mij), den fooru disi, di n abi moi wiri a den stjin (deze vogels, die geen mooie veren hebben), mi si a ooru froo dati, ben sdon a skoinswenkri (ik zag die oude vrouw, zat bij schuinswinkel).

In het hierboven geschetste systeem worden de structurele mogelijkheden opgegeven. Het spreekt vanzelf, dat monsterconstructies als:

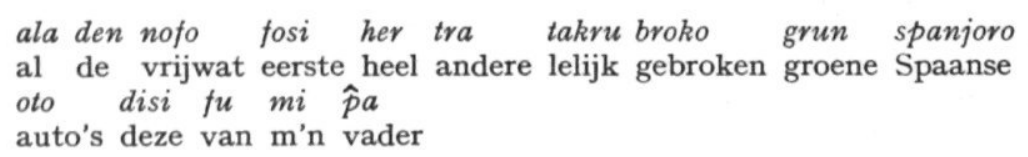

in principe wel mogelijk zijn, maar in het normale spraakgebruik niet voorkomen. De taalgebruiker doet slechts een beperkte keuze uit de vele structurele mogelijkheden.

Het hierboven geschetste systeem wordt gecompliceerd doordat niet alle woorden uit de telwoordgroep gecombineerd kunnen worden met alle woorden uit de enkri-groep. Zo kan men bijvoorbeeld wel wawan (enkele verspreide) combineren met enkri (enkele), maar niet wantu (enkele). Wij zouden de individuele combinatiemogelijkheden precies kunnen beschrijven, maar dit heeft weinig zin, vooral zolang wij niet alle woorden uit de telwoordgroep en de enkri-groep kennen.

Het is dikwijls de vraag, waar de grenzen van de structurele taalbeschrijving liggen. Een taalstructuur kan niet volledig beschreven worden evenmin als de woordenschat van een taal. Een taal kent zo oneindig veel mogelijkheden, dat een mensenleven niet voldoende zou zijn om hen alle op te sporen. Wij noemden in het schema vijf woorden uit de enkri-groep. Wij zijn er echter van overtuigd dat verder onderzoek minstens nog eens vijf woorden uit deze groep aan het licht zou brengen. Ook dan zou echter de groep niet volledig gekend zijn. Dit geldt zeer zeker voor de voorbepalingen van de derde graad. Men zou maanden moeten werken en taalgebruik moeten observeren om deze vijf woorden op te sporen en dan nog eens maanden om de combinatiemogelijkheden met de telwoordgroep na te gaan. Dan zou men nog geen volledige inventaris bezitten. Perfectionisme in deze richting is daarom zinloos. In structureel opzicht weet men dan omtrent deze groep nog niet meer dan nu. Wij kennen structureel deze groep namelijk nu reeds: wij kennen immers zijn plaats in de substantiefgroep (voorbepaling van de vijfde graad).

Men zal hierna wellicht een verband willen leggen met de traditionele grammatica, die spreekt van bijvoegelijk naamwoord, telwoord etc. De termen zijn niet belangrijk. Structureel is slechts belangrijk het onderscheid tussen voor- en achterbepalingen en de volgorde der bepalingen. Om redenen van utiliteit kan men de voorbepalingen van de zevende graad artikel noemen en de voorbepalingen van de zesde graad telwoord. Op deze wijze wordt een nuttig verband gelegd met ons reeds uit de traditionele grammatica bekende termen. Structureel is echter niet belangrijk dat het telwoorden zijn, maar dat telwoorden voorbepalingen van de zesde graad zijn. In verband met bovenstaande feiten lijkt het ons ongewenst de term adjectivum (bijvoegelijk naamwoord) te gebruiken. Onder deze term 
zou men immers een aantal categorieën moeten verzamelen, waardoor essentiële structurele onderscheidingen worden verwaarloosd.

Ons onderzoek naar de bouw van de substantiefgroep in het Sranan leidde niet tot spectaculaire resultaten. Dit was ook niet te verwachten. Toch menen wij dat het zeer verhelderend is geweest. In ieder geval is het nuttig, dat wij de traditionele en ook in structurele studies over het Sranan ${ }^{1}$ ) steeds gehanteerde term adjectivum hebben leren analyseren in een aantal duidelijk onderscheiden categorieën en daarmee onze kennis omtrent de structuur van het Sranan hebben verrijkt.

\section{SUMMARY}

\section{STUDY OF THE STRUCTURE OF SRANAN}

This article brings together the results of further study conducted at various times in the structure of Sranan. Section one (Linguistic Analysis) consists of an answer to questions raised in Surinam, in reaction to the author's dissertation, regarding the applicability of the structural method of analysis to languages such as Sranan. This 'declaration of principles' serves as a justification for further research. There need not be any fear of unclearly delimited linguistic categories. It is possible, however, that as a result of intensive contact with the official language of Surinam, Dutch, structural uncertainties arise in Sranan. This problem is considered in section two (Language Development in Action) in connection with the system of adjuncts of place. Section three (The System of Personal Pronouns) demonstrates what use the work of other descriptive linguists is put to in the study being made. Father DonICIE's description of the personal pronouns forms the point of departure, while HALL's work is also examined critically and his analysis is repeated on the same texts. The fourth and final section (The Structure of the Substantive Group) comprises a description of an aspect of the language which has received little or no attention up to the present.

1) Zie Robert A. Hall JR: The Linguistic Structure of Taki-Taki. Language 24, 1948, p. 101. 